\title{
The potential therapeutic role of Fenugreek saponin against Alzheimer's disease: Evaluation of apoptotic and acetylcholinesterase inhibitory activities
}

\author{
Wagdy K. B. Khalil*, Hanaa M. Roshdy, Salwa M. Kassem \\ Cell Biology Department, National Research Centre (NRC), 33 EL Bohouth St., Dokki, Giza, Egypt.
}

\begin{tabular}{l} 
ARTICLE INFO \\
\hline Article history: \\
Received on: $14 / 06 / 2016$ \\
Revised on: 12/07/2016 \\
Accepted on: 08/08/2016 \\
Available online: 26/09/2016 \\
\hline Key words: \\
Apoptosis, \\
Acetylcholinesterase \\
inhibition activity, Trigonella \\
foenum-graecum, apoptotic \\
related genes
\end{tabular}

\begin{abstract}
Alzheimer disease $(\mathrm{AD})$ is known as lacking in the neuro-transmitters within the brain cells due to increase the Acetylcholinesterase (AchE) activity. So, use of AchE inhibitors (AchEI) is believed to be the best way in treatment of Alzheimer. Therefore, the aim of the present work was to evaluate the AchEI and apoptotic activities of fenugreek saponin against $\mathrm{AD}$ in vivo. Ninety male aged Sprague Dawley rats were allocated in several experimental groups including untreated animals, supplemented animals with $0.05 \%, 0.1 \%$ and $2 \%$ of fenugreek saponin (FS), animals treated with $\mathrm{AlCl}_{3}$ to induce $\mathrm{AD}, \mathrm{AD}$-induced animals treated with the previous doses of FS or with Rivastigmine. Brain tissues of different groups were used for determine the AchEI and apoptotic activities as well as generation of reactive oxygen species (ROS), DNA damage and expression of apoptotic related genes (Bax; Bcl2 and caspase-3). The results showed that FS increased the AChEI and apoptosis activities as well as elevated the gene expression levels of Bax; $\mathrm{Bcl} 2$ and caspase- 3 genes in ADinduced rats. However, FS decreased the ROS generation and DNA damage in AD-induced rats compared with control rats. The results suggested that the ability of fenugreek saponin to inhibit AD due to increase AChE inhibition activity might be attributed to increase the antioxidants in this herb. Moreover, enhancement the apoptosis by fenugreek saponin could be attributed mainly to the regulation process of Bax, $\mathrm{Bcl}-2$ and casapse-3 in the apoptotic pathway and not by generation of ROS in the brain cells of the AD-induced rats.
\end{abstract}

\section{INTRODUCTION}

Alzheimer's disease (AD) is considered as a neurological degenerative disorder of the brain tissues. It is known as the most widespread form of insanity among the aged inhabitants (Kim et al., 2009). Alzheimer's society recorded that $13 \%$ of the American population beyond age of 65 years and $50 \%$ of the Americans higher than 85 years in age have been currently estimated as AD's patients (Kim et al., 2009). Therefore, increasing the number of AD patients which reaching several million in the near future (Kim et al., 2009; Heo et al., 2004; Prasad et al., 2000; Terry and Masliah, 1991) needs a lot of money for the health care scheme of the AD (Kim et al., 2009).

\footnotetext{
* Corresponding Author
}

Email:wagdykh@hotmail.com
Absence of cholinergic connections in several parts of the brain such as neocortex and hippocampus has been found to be main reason of $\mathrm{AD}$. This fact highlights the requirement to utilize a considerable challenge that regulates the acetylcholinesterase (AChE) role to overcome this failing (Kim et al., 2009).

Several medicines such as rivastigmine and donepezil are used for therapy this disorder as AChE inhibitors which are approved by several global Food and Drug societies (Kim et al., 2009; Candy et al., 1983; Loizzo et al., 2008). In despite of using these inhibitors for regulating the function of the AChE there are increment need to pursuit for new medicaments (Kim et al., 2009). Therefore, several studies for this purpose aimed to find new natural compounds having possible antioxidative properties and with very low side effects have been carried out (Kim et al., 2009, Ak and Gulcin, 2008; Gulcin, 2006; Burda and Oleszek, 2001; Cardenas et al., 2006; Li et al., 2008; Kris-Etherton et al., 2002). 
Consequently, there is rising spotlight on use imitative herbal medicines for AD treatment (Drever et al., 2008). As already known, acetylcholine is main neurotransmitter playing critical role in AD is acetylcholine (Akhondzadeh et al., 2003). For that reason, there have been multiple research to use AChE suppressors. One of the important plants having the antioxidant properties is Trigonella foenum graecum L namely, fenugreek. Its seeds and leaves are used for food and also in traditional medicine (Sharma et al., 1996; Warrior and Nambiar, 1995). Some studies reported that trigonelline, a compound isolated from fenugreek, exhibited nerve regeneration and improved memorial activity in AD-induced mice (Tohda et al., 2005). Therefore, in India prepared bread from fenugreek seeds, wheat and maize is used for general population as protection against several diseases including AD. It has been found that fenugreek seeds have many of compounds such as steroidal saponin, vitamins and oils considered as very important materials for medical applications (Jayaweera, 1981). These compounds and materials have been used against ulcer (Almeshal et al., 1985), CNS degeneration (Natrajan et al., 2007), immune diseases (Bilal et al., 2003), oxidation (Kaviarasan et al.,2007). In addition, fenugreek saponin has been reported to have apoptosis activity (Moalic et al., 2001). It has been found that fenugreek saponin is able to inhibit cell proliferation in the tumor cell line by stimulation of apoptosis and arrest of the cell cycle (Moalic et al., 2001). It has been suggested that fenugreek saponin caused apoptotic stimulation and cell cycle arrest mostly by enhancing the gene expression of the onco-protein p53 (Corbiere et al., 2003). However, for our knowledge there are no published data available concerning the possible therapeutic effect of fenugreek saponin on AD. Therefore, the idea of the present study is to evaluate the apoptotic and acetylcholinesterase inhibitory activities of fenugreek saponin against $\mathrm{AD}$ in vivo.

\section{MATERIAL AND METHODS}

\section{Drugs and Reagents}

Aluminium Chloride $\left(\mathrm{AlCl}_{3}\right.$, M.W. 133.34.): was purchased from Sigma. Rivastigmine: Exelon $1.5 \mathrm{mg}$, was purchased from Novartis Co. Trizol was bought from Invitrogen (Carlsbad, CA, USA). The reverse transcription and PCR kits were obtained from Fermentas (Glen Burnie, MD, USA). SYBR Green Mix was purchased from Stratagene (La Jolla, CA, USA).

\section{Fenugreek saponin}

An $80 \%$ methanol extract of fenugreek seeds was produced by grinding seeds to a fine powder and mixing with $80 \%$ methanol over night. Saponins were extracted from fenugreek seeds ( $T$. foenum-graecum L.) seeds generally according to Marston and Oleszek (2000).

\section{Experimental Animals}

Ninety male aged Sprague Dawley rats (14-16 months) weighing 250-300 g (purchased from the Animal House Colony, Giza, Egypt) were maintained on standard laboratory diet and water ad libitum at the Animal House Laboratory, National Research Center, Dokki, Giza, Egypt. After an acclimation period of 1 week, animals were divided into groups (10 rats/ group) and housed individually in filter-top polycarbonate cages, housed in a temperature-controlled $\left(23 \pm 1^{\circ} \mathrm{C}\right)$ and artificially illuminated (12 $\mathrm{h}$ dark/light cycle) room free from any source of chemical contamination. All animals received humane care in compliance with the guidelines of the Animal Care and Use Committee of National Research Center, Egypt.

\section{Experimental Design}

Rats were randomly assigned into nine groups, ten rats each. The first group served as normal control. The second to fourth groups were fed experimental diets containing $0.05 \%, 0.1 \%$ and $2 \%$ of fenugreek saponin (FS) forty five days, respectively. The fifth group was provided with $\mathrm{AlCl}_{3}$ in drinking water in a dose of $0.3 \%$ for forty five days (Erazi et al., 2010), and served as $\mathrm{AD}$ intoxicated group. The sixth to eighth groups rats were given $\mathrm{AlCl}_{3}$ in drinking water daily for forty five days then were fed experimental diets containing $0.05 \%, 0.1 \%$ and $2 \%$ of fenugreek saponin, respectively, for another forty five days (Hussein, 2008). The ninth group rats were given $\mathrm{AlCl}_{3}$ in drinking water daily for forty five days then they were orally treated with Rivastigmine in a dose of $0.3 \mathrm{mg} / \mathrm{kg}$ b. wt. (Carageorgious et al., 2008) as a reference drug daily for another forty five days.

\section{Tissue Collection}

At the end of experimental period the animals were sacrificed under anesthesia and the brains were rapidly dissected, thoroughly washed with isotonic saline. The each brain was midsaggitally divided into two portions. The first portion was stored in liquid nitrogen for gene expression analysis and the second portion was homogenized, centrifuged under cooling at $3000 \mathrm{rpm}$ for 10 min for biochemical analyses.

\section{Apoptosis assay}

The brain tissues (100 $\mathrm{mg}$ per sample) were made into single-cell suspensions according to method of Villalba et al. (1992). Cells apoptosis was determined by flow cytometry (FCM) assay using Annexin V/PI apoptosis detection kit. The single-cell suspension $\left(1 \times 10^{6}\right.$ cells $\left./ \mathrm{mL}\right)$ was suspended in $200 \mu \mathrm{L}$ ice-cold binding buffer and then $10 \mu \mathrm{L}$ horseradish peroxidase FITC labeled Annexin $\mathrm{V}$ and $5 \mu \mathrm{L}$ propidium iodide (PI) were added. The cell suspension was incubated in darkness at room temperature for $15 \mathrm{~min}$. Apoptosis rate was determined by flow cytometer. In this study, both FITC and PI negative cells were considered as normal cells. FITC-single positive and PI negative cells were defined as early apoptotic cells, while both FITC and PI positive cells were considered as late apoptotic or necrosis cells.

\section{Determination of ROS formation}

Intracellular ROS generation was measured in brain tissues by a flow cytometer with an oxidation-sensitive DCFH-DA 
fluorescent probe, after single-cell suspensions were made. DCFHDA is a non-fluorescent compound that is freely taken up into cells. DCFH is oxidized to fluorescent dichlorofluorescein (DCF) by the action of cellular oxidants. The suspension was loaded by DCFH-DA solution with a final concentration of $50 \mu \mathrm{M}$ and was incubated for $30 \mathrm{~min}$ at $37^{\circ} \mathrm{C}$. Then samples were centrifuged at $1000 \mathrm{rpm}$ for $5 \mathrm{~min}\left(4^{\circ} \mathrm{C}\right)$, and cells were resuspended with phosphate buffered saline (PBS, $\mathrm{pH} 7.2-7.4)$. The fluorescence was detected by flow cytometer (with excitation $488 \mathrm{~nm}$ and emission $525 \mathrm{~nm}$ ). For each treatment, $1 \times 10^{5}$ cells were counted, and the experiment was performed in triplicate.

\section{Determination of $\mathrm{AChE}$ activity}

AChE activity was measured in brain tissues using a 96well microplatereader (Ellman et al., 1961; Mukherjee et al., 2007). The enzyme hydrolyzes the substrate acetylthiocholine resulting in the product thiocholine which reacts with Ellman's reagent (DTNB) to produce2-nitrobenzoate-5-mercaptothiocholine and 5-thio-2- nitrobenzoate which can be detected at $405 \mathrm{~nm}$. In the 96-well plates, $125 \mathrm{ml}$ of $3 \mathrm{mM}$ DTNB, $25 \mathrm{ml}$ of $15 \mathrm{mM}$ ATCI, 50 $\mu \mathrm{l}$ of buffer and $25 \mu \mathrm{l}$ of sample dissolved in phosphate buffer were added. The absorbance was measured at $405 \mathrm{~nm}$ every $13 \mathrm{~s}$ for $65 \mathrm{~s} .25 \mathrm{ml}$ of $0.22 \mathrm{U} / \mathrm{ml}$ of AChE enzyme was then added and the absorbance was again read every $13 \mathrm{~s}$ for $104 \mathrm{~s}$. The absorbance was read using a BioRad micro-plate reader at $405 \mathrm{~nm}$. Absorbance was plotted against time and enzyme activity was calculated from the slope of the line so obtained and expressed as a percentage compared to an assay using a buffer without any inhibitor.

\section{Gene Expression Analysis Isolation of Total RNA}

TRIzol $^{\circledR}$ Reagent (Invitrogen, Germany) was used to extract total RNA from brain tissues of male rats according to the manufacturer's instructions with minor modifications. Isolated total RNA was treated with one unit of RQ1 RNAse-free DNAse (Invitrogen, Germany) to digest DNA residues, re-suspended in DEPC-treated water and quantified photospectrometrically at 260 nm. Purity of total RNA was assessed by the 260/280 nm ratio which was between 1.8 and 2.1. Additionally, integrity was assured with ethidium bromide-stain analysis of $28 \mathrm{~S}$ and $18 \mathrm{~S}$ bands by formaldehyde-containing agarose gel electrophoresis (data not shown). Aliquots were used immediately for reverse transcription (RT), otherwise they were stored at $-80^{\circ} \mathrm{C}$.

\section{Reverse Transcription (RT) Reaction}

Complete Poly $(\mathrm{A})^{+}$RNA isolated from brain tissues was reverse transcribed into cDNA in a total volume of $20 \mu \mathrm{l}$ using RevertAid $^{\mathrm{TM}}$ First Strand cDNA Synthesis Kit (Fermentas, Germany). An amount of total RNA $(5 \mu \mathrm{g})$ was used with a master mix consisting of $50 \mathrm{mM} \mathrm{MgCl} 2,10 x$ RT buffer, $10 \mathrm{mM}$ of each dNTP, $50 \mu \mathrm{M}$ oligo-dT primer, 20 IU ribonuclease inhibitor and 50 IU MuLV reverse transcriptase. The mixture of each sample was centrifuged for $30 \mathrm{sec}$ at $1000 \mathrm{~g}$ and transferred to the thermocycler. The $\mathrm{RT}$ reaction was carried out at $25^{\circ} \mathrm{C}$ for $10 \mathrm{~min}$, followed by $1 \mathrm{~h}$ at $42^{\circ} \mathrm{C}$, and finished with a denaturation step at $99^{\circ} \mathrm{C}$ for $5 \mathrm{~min}$. Afterwards the reaction tubes containing RT preparations were flash-cooled in an ice chamber until being used for cDNA amplification through quantitative Real Timepolymerase chain reaction (qRT-PCR).

\section{Real Time-PCR (qPCR)}

QIAGEN's real-time PCR cycler (Rotor-Gene Q, USA) was used to determine the cortex cDNA copy number. PCR reactions were set up in $25 \mu \mathrm{L}$ reaction mixtures containing 12.5 $\mu \mathrm{L} 1 \times \mathrm{SYBR}^{\circledR}$ Premix Ex TaqTM (TaKaRa, Biotech. Co. Ltd.), $0.5 \mu \mathrm{L} 0.2 \mu \mathrm{M}$ sense primer, $0.5 \mu \mathrm{L} 0.2 \mu \mathrm{M}$ antisense primer, 6.5 $\mu \mathrm{L}$ distilled water, and $5 \mu \mathrm{L}$ of cDNA template. The reaction program was used as follows: a number of 40 cycles was used in which each cycle divided to: (a) at $95.0^{\circ} \mathrm{C}$ for $15 \mathrm{sec}$; (b) at $55.0^{\circ} \mathrm{C}$ for $30 \mathrm{sec}$; and (c) at $72.0^{\circ} \mathrm{C}$ for $30 \mathrm{sec}$. afterwards, a last step consisted of 71 cycles which started at $60.0^{\circ} \mathrm{C}$ and then increased about $0.5^{\circ} \mathrm{C}$ every $10 \mathrm{sec}$ up to $95.0^{\circ} \mathrm{C}$. At the end of each sqRTPCR a melting curve analysis was performed at $95.0^{\circ} \mathrm{C}$ to check the quality of the used primers. The sequences of specific primer of the genes used are listed in Table 1. At the end of each qRTPCR a melting curve analysis was performed at $95.0^{\circ} \mathrm{C}$ to check the quality of the used primers.

Table 1: Primer sequences used for $\mathrm{qPCR}$

\begin{tabular}{lll}
\hline \multirow{2}{*}{ Gene } & Primer sequence (5'-3') & $\begin{array}{l}\text { References/ } \\
\text { NCBI }\end{array}$ \\
\hline \multirow{2}{*}{ Bax } & F: CGA GCT GAT CAG AAC CAT CA & NM- \\
& R: CTC AGC CCA TCT TCT TCC AG & 017059.2 \\
\hline \multirow{2}{*}{ Bcl2 } & F: CTC AGT CAT CCA CAG GGC GA & Khalil and \\
& R:AGA GGG GCT ACG AGT GGG AT & Booles [32] \\
\hline \multirow{2}{*}{ Caspase 3 } & F: GGA CCT GTG GAC CTG AAA AA & NM- \\
& R: GCA TGC CAT ATC ATC GTC AG & 012922.2 \\
\hline \multirow{2}{*}{$\beta$-actin } & F: CAC GTG GGC CGC TCT AGG CAC CAA & Khalil and \\
& R: CTC TTT GAT GTC ACG CAC GAT TTC & Booles [32] \\
\hline
\end{tabular}

To calculate the gene expression levels the amplification efficiency (Ef) was calculated from the slope of the standard curve using the following formula found in the manufacturer's instruction pamphlet: $\mathrm{Ef}=10^{-1 / \text { slope }}, \operatorname{Efficiency}(\%)=(\mathrm{Ef}-1) \times 100$ The relative quantification of the target to the reference was determined by using the $2^{-\Delta \Delta \mathrm{CT}}$ method if Ef for the target (Bax; $\mathrm{Bcl} 2$ and caspase 3 ) and the reference primers ( $\beta$-Actin) as follows:

$$
\begin{aligned}
& \Delta \mathrm{C}_{\mathrm{T}(\text { test })}=\mathrm{C}_{\mathrm{T}(\text { target, test })}-\mathrm{C}_{\mathrm{T} \text { (reference, test })}, \\
& \Delta \mathrm{CT} \text { (calibrator) }=\mathrm{C}_{\mathrm{T}(\text { target, calibrator })}-\mathrm{C}_{\mathrm{T}(\text { reference, calibrator })}, \\
& \Delta \Delta \mathrm{CT}=\Delta \mathrm{C}_{\mathrm{T}(\text { Test })}-\Delta \mathrm{C}_{\mathrm{T} \text { (calibrator) }} .
\end{aligned}
$$

The relative expression was calculated by $2^{-\Delta \Delta \mathrm{CT}}$.

\section{Comet assay}

Isolated brain tissues of all groups of rats were subjected to the modified single-cell gel electrophoresis or comet assay (Fairbairn et al., 1995). In brief, the protocol for electrophoresis involved embedding of the isolated cells in agarose gel on microscopic slides and lysing them with detergent at high salt concentrations overnight (in the cold). The cells were treated with alkali for $20 \mathrm{~min}$ to denature the DNA and electrophoresis under 
alkaline conditions (30 min) at $300 \mathrm{~mA}, 25 \mathrm{~V}$. The slides were stained with ethidium bromide and examined using a fluorescence microscope with a green filter at $\times 40$ magnification. For each animal about 100 cells were examined to determine the percentage of cells with DNA damage that appear like comets. The nonoverlapping cells were randomly selected and were visually assigned a score on an arbitrary scale of 0-3 (i.e., class $0=$ no detectable DNA damage and no tail; class $1=$ tail with a length less than the diameter of the nucleus; class $2=$ tail with length between $1 \times$ and $2 \times$ the nuclear diameter; and class $3=$ tail longer than $2 \times$ the diameter of the nucleus) based on perceived comet tail length migration and relative proportion of DNA in the nucleus (Collins et al., 1997).

\section{RESULTS}

\section{Effect of FS on rate of the apoptosis}

Determination the effect of different doses of FS on apoptosis induction in brain tissues of male rats was carried out (Fig. 1). The results indicated that FS increased the rates of apoptosis in healthy rats by 259.8, 312.2 and $522 \%$ when they treated with low, medium and high doses of FS, respectively, compared with control rats (Fig. 1).

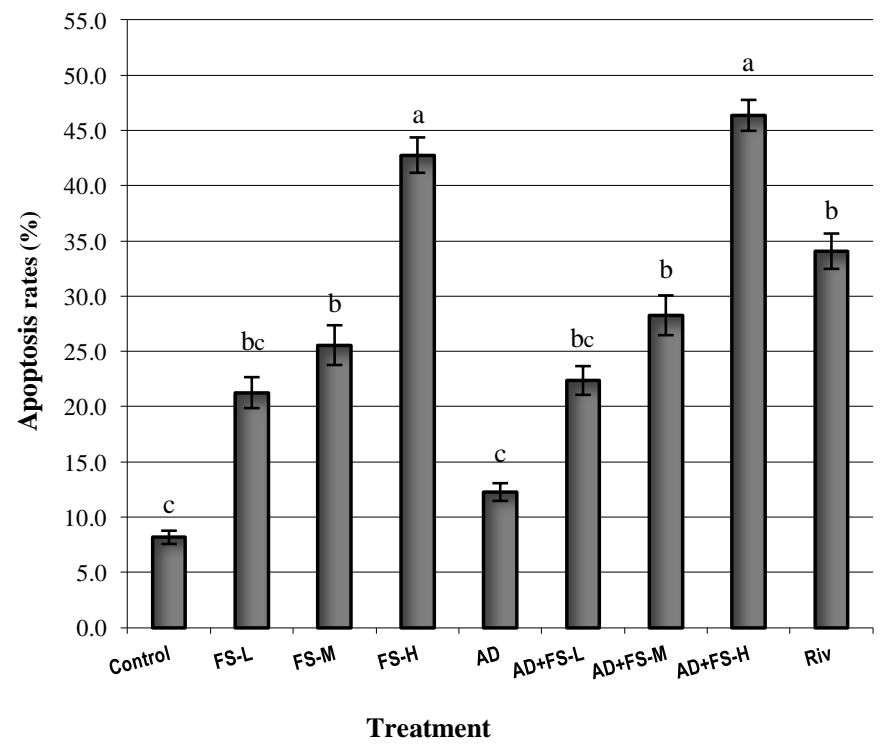

Fig. 1: Alterations in apoptosis rate in brain tissues of healthy or AD-induced rats treated with different doses of fenugreek saponin (FS). Data are presented as mean \pm SEM. ${ }^{\text {a,b,c }}$ Mean values within tissue with unlike superscript letters were significantly different $(P<0.05)$.

Moreover, similar rates of apoptosis were found in brain tissues of AD-induced rats when they treated with FS compared with control rats. The rates of apoptosis were equal to 273.2, 345.1 and $565.9 \%$ in brain tissues of AD-induced rats treated with low, medium and high doses of FS, respectively compared with control rats. Furthermore, treatment of $\mathrm{AD}$-induced rats with rivastigmine induced rate of apoptosis similar to those induced by medium dose of FS. However, less apoptosis rate was found in brain tissues of AD-induced rats (Fig. 1).

\section{Effect of FS on ROS generation}

Measurement of the intracellular ROS generation in brain tissues of male rats is summarized in Fig. 2. The results showed that high level of intracellular ROS generation with a significant difference $(\mathrm{P}<0.01)$ was found in $\mathrm{AD}$-induced rats compared with control rats. However, low intracellular ROS generation similar to those in control rats was found brain tissues of male rats treated with the all doses of FS. Moreover, treatment of AD-induced rats with FS decreased the intracellular ROS generation compared with those in untreated $\mathrm{AD}$-induced rats. The decrease in the intracellular ROS generation in $\mathrm{AD}$-induced rats was found in the treatment with all doses of FS, where the lowest intracellular ROS generation was found with the high dose of FS. On the other hand, treatment of $\mathrm{AD}$-induced rats with rivastigmine decreased the intracellular ROS generation similar to those induced by high dose of FS (Fig. 2).

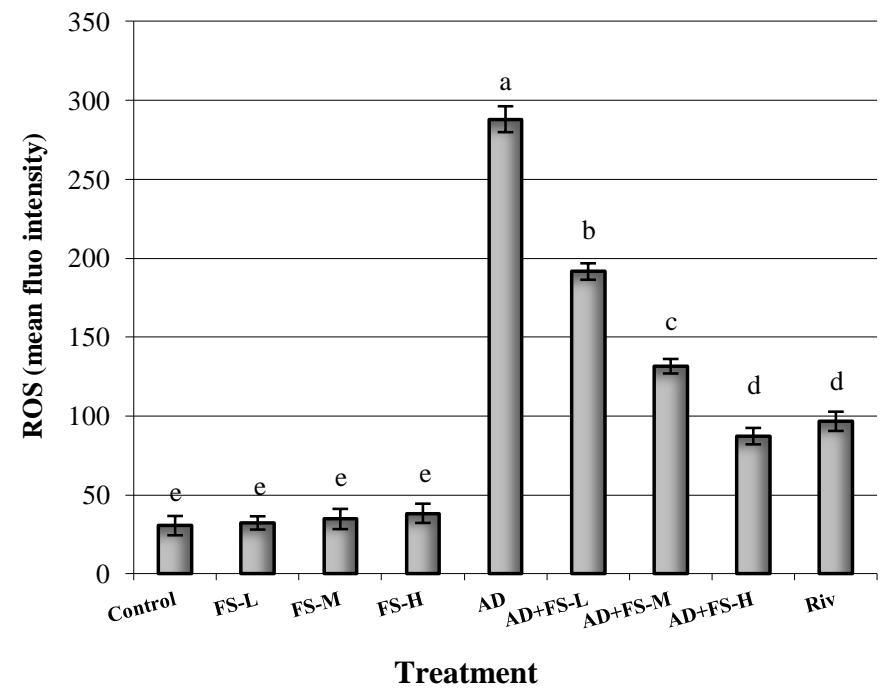

Fig. 2: Intracellular ROS levels in brain tissues of healthy or AD-induced rats treated with different doses of fenugreek saponin (FS). Data are presented as mean \pm SEM. ${ }^{\text {a,b,c,d }}$ Mean values within tissue with unlike superscript letters were significantly different $(P<0.05)$.

\section{Effect of FS on the AChE inhibitory activity}

Table 2 shows the effect of different doses of FS on the levels of AChE inhibitory activity. The results found that FS increased significantly the levels of AChE inhibitory activity in male rats by 4, 7 and 9-fold increase when they treated with low, medium and high doses of FS, respectively, compared with control rats (Table 2). In addition, relatively similar mean levels of AChE inhibitory activity were found in brain tissues of AD-induced rats when they treated with FS compared with control rats. The mean values of AChE inhibitory activity were increased by $4.5,8$ and 10.6-fold increase in brain tissues of AD-induced rats treated with low, medium and high doses of FS, respectively compared with control rats. Moreover, treatment of $\mathrm{AD}$-induced rats with 
rivastigmine increased the levels of AChE inhibitory activity similar to those induced by medium dose of FS (Table 2).

Table 2: Acetylcholinesterase Inhibitory activity in different treatments by fenugreek saponin.

\begin{tabular}{lc}
\hline Treatment & $\begin{array}{c}\text { IC }_{\mathbf{5 0}} \text { values of } \mathbf{A C h E} \\
\text { inhibitory activity }(\boldsymbol{\mu g} / \mathbf{m l})\end{array}$ \\
\hline Control & $8.2 \pm 2.3^{\mathrm{c}}$ \\
Fenugreek saponin-low & $32.1 \pm 4.2^{\mathrm{b}}$ \\
Fenugreek saponin-medium & $58.7 \pm 6.1^{\mathrm{a}}$ \\
Fenugreek saponin-high & $78.4 \pm 7.3^{\mathrm{a}}$ \\
Alzheimer & $13.6 \pm 3.2^{\mathrm{c}}$ \\
Alzheimer + Fenugreek saponin-low & $36.2 \pm 7.6^{\mathrm{b}}$ \\
Alzheimer + Fenugreek saponin-medium & $64.1 \pm 9.2$ \\
Alzheimer + Fenugreek saponin-high & $85.6 \pm 8.4$ \\
Rivastigmine & $62.3 \pm 7.7$ \\
\hline
\end{tabular}

$\mathrm{IC}_{50}=$ half maximal inhibitory concentration $\left(\mathrm{IC}_{50}\right)$. Data are presented as mean \pm SEM. ${ }^{\text {a,b,c }}$ Mean values within tissue with unlike superscript letters were significantly different $(P<0.05)$

\section{Effect of FS on the expression alteration of apoptotic related} genes

Expression of Bax, Bcl 2 and caspase- 3 genes quantified by real-time RT-PCR is summarized in Figures 3-5. The results found that low expression levels of $\mathrm{Bax}, \mathrm{Bcl} 2$ and caspase- 3 genes in control rats was in same line with those in $\mathrm{AD}$-induced rats.

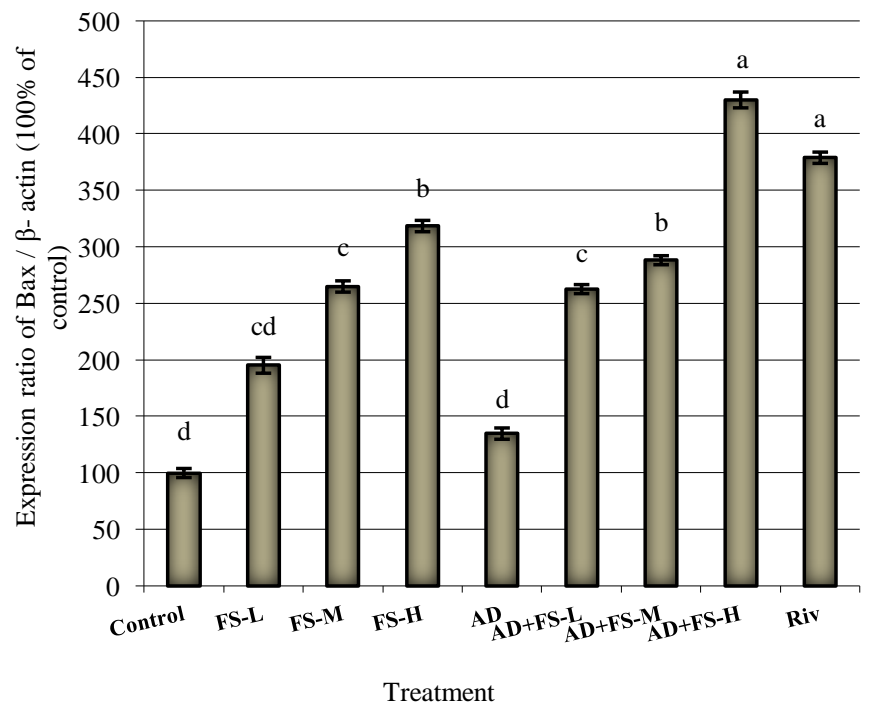

Fig. 3: Expression of Bax gene in the brain tissues of healthy or $A D$-induced rats treated with different doses of fenugreek saponin (FS) determined by quantitative RT-PCR. Data are presented as mean \pm SEM. ${ }^{\text {a,b,c,d }}$ Mean values within tissue with unlike superscript letters were significantly different $(P<$ $0.05)$.

In contrary, FS treatment increased significantly the mRNA expression levels of $\mathrm{Bax}, \mathrm{Bcl} 2$ and caspase- 3 genes compared with control rats. The expression of Bax gene in male rats treated with low, medium and high doses of FS was increased to $195.3,265.1$ and $318.6 \%$ of control, respectively (Figure 3-5). The expression of $\mathrm{Bcl} 2 \mathrm{mRNA}$ in male rats treated with low, medium and high doses of FS was increased to 256.7, 321.6 and $345.9 \%$ of control, respectively. Also, the expression of caspase- 3 mRNA in male rats treated with low, medium and high doses of
FS was increased to $264.3,350.0$ and $392.8 \%$ of control, respectively. Moreover, the expression of $\mathrm{Bax}, \mathrm{Bcl} 2$ and caspase- 3 genes was highly over-expressed in $\mathrm{AD}$-induced rats treated with the all doses of the FS. The expression of Bax, Bcl2 and caspase-3 genes in $\mathrm{AD}$-induced rats treated with low, medium and high doses of FS compared to control was increased to 262.8, 288.3 and $430.2 \%$ for Bax; 329.7, 354.1 and 470.3 for Bcl2; and 328.6, 450.1 and 567.8 for caspase-3 gene, respectively (Figure 3-5). Moreover, treatment of $\mathrm{AD}$-induced rats with rivastigmine increased the expression levels of $\mathrm{Bax}, \mathrm{Bcl} 2$ and caspase- 3 genes similar to those of high dose of FS (Figure 3-5).

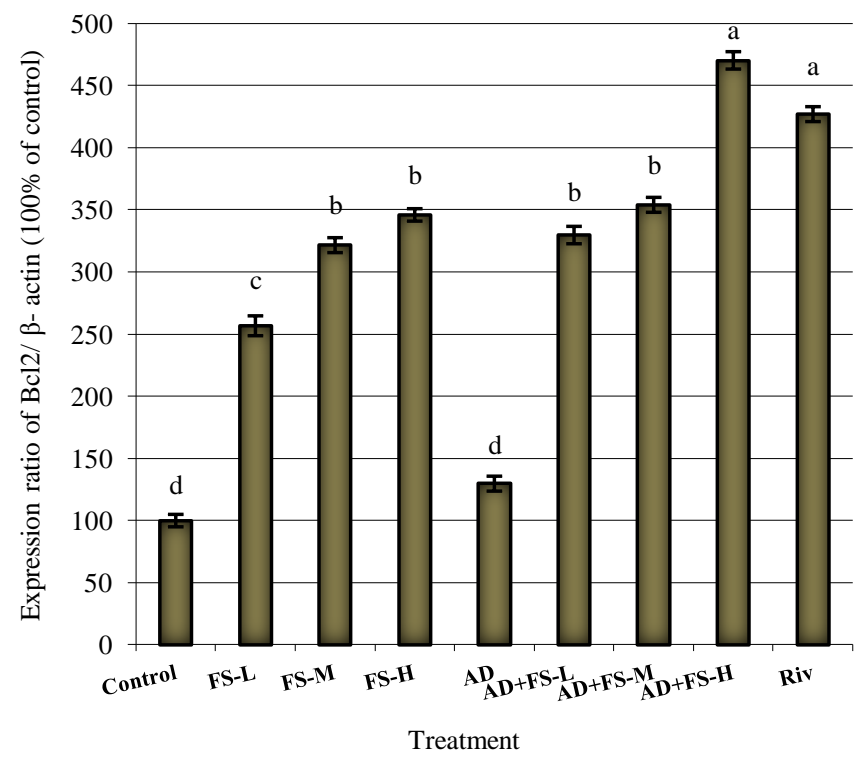

Fig. 4: Expression of $\mathrm{Bcl} 2$ gene in the brain tissues of healthy or $\mathrm{AD}$-induced rats treated with different doses of fenugreek saponin (FS) determined by quantitative RT-PCR. Data are presented as mean \pm SEM. ${ }^{\text {a,b,c,d }}$ Mean values within tissue with unlike superscript letters were significantly different $(P<$ $0.05)$.

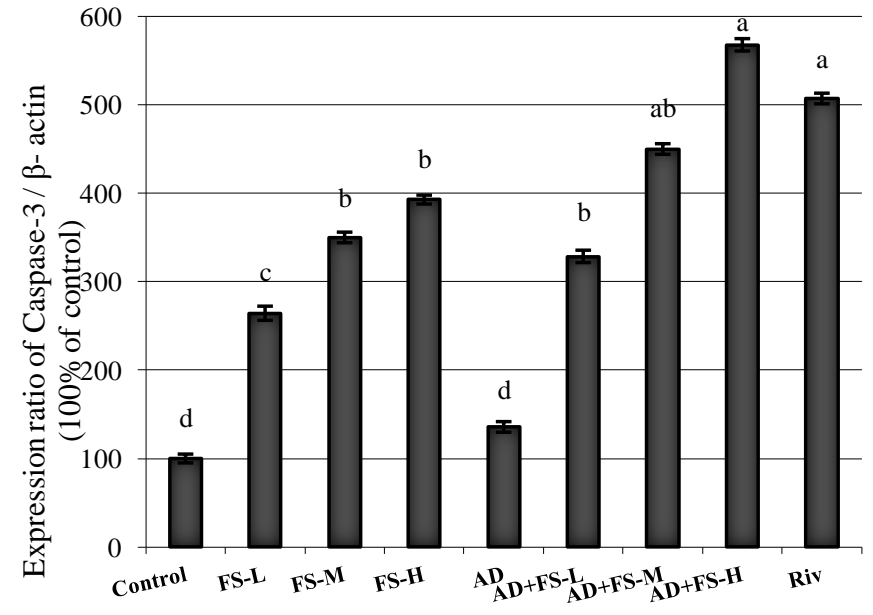

Treatment

Fig. 5: Expression of Caspase-3 gene in the brain tissues of healthy or ADinduced rats treated with different doses of fenugreek saponin (FS) determined by quantitative RT-PCR. Data are presented as mean \pm SEM. ${ }^{\text {a,b,c,d }}$ Mean values within tissue with unlike superscript letters were significantly different $(P<$ $0.05)$. 


\section{Effect of FS on DNA damage}

Table 3 shows the rates of DNA damage determined by comet assay. The results observed that significantly high rate of DNA damage was found in $\mathrm{AD}$-induced rats compared with control rats. However, low rates of DNA damage similar to those in control rats was found brain tissues of rats treated with the all doses of FS. Additionally, treatment of AD-induced rats with FS decreased the rate of DNA damage compared with those in untreated $\mathrm{AD}$-induced rats. The decrease in the rate of DNA damage in $\mathrm{AD}$-induced rats was found in the treatment with all doses of FS, where the lowest rate of DNA damage was found with the high dose of FS. On the other hand, treatment of ADinduced rats with rivastigmine decreased the rate of DNA damage similar to those induced by high dose of FS (Fig. 2).

Table 3: Visual score of DNA damage in brain tissues of different treatments by fenugreek saponin.

\begin{tabular}{|c|c|c|c|c|c|c|c|}
\hline \multirow[b]{2}{*}{ Treatment } & \multicolumn{2}{|c|}{ No. of cells } & \multicolumn{4}{|c|}{ Class $^{* * *}$} & \multirow{2}{*}{$\begin{array}{c}\text { DNA } \\
\text { damaged } \\
\text { cells \% }\end{array}$} \\
\hline & Analyzed & Comets & $\mathbf{0}$ & 1 & 2 & 3 & \\
\hline Control & 500 & 37 & 463 & 24 & 13 & 0 & 7.4 \\
\hline FS-L & 500 & 36 & 464 & 23 & 12 & 1 & 7.2 \\
\hline FS-M & 500 & 38 & 462 & 21 & 15 & 2 & 7.6 \\
\hline FS-H & 500 & 41 & 459 & 22 & 13 & 5 & 8.2 \\
\hline AD & 500 & 113 & 387 & 31 & 43 & 39 & 22.6 \\
\hline AD+FS-L & 500 & 101 & 399 & 32 & 35 & 34 & 20.2 \\
\hline AD+FS-M & 500 & 89 & 411 & 29 & 32 & 28 & 17.8 \\
\hline AD+FS-H & 500 & 71 & 429 & 24 & 26 & 21 & 14.2 \\
\hline Riv & 500 & 79 & 421 & 24 & 29 & 26 & 15.8 \\
\hline
\end{tabular}

*: Number of cells examined per a group $(n=5), \stackrel{* *}{ }$ : Class $0=$ no tail; $1=$ tail length < diameter of nucleus; $2=$ tail length between $1 \mathrm{X}$ and $2 \mathrm{X}$ the diameter of nucleus; and $3=$ tail length $>2 \mathrm{X}$ the diameter of nucleus.

\section{DISCUSSION}

This study aimed to evaluate the apoptotic and acetylcholinesterase inhibitory activities of fenugreek saponin against $\mathrm{AD}$ in vivo as novel therapeutic tool for Alzheimer disorder. The results of the present work found that fenugreek saponin increased significantly the AChE inhibitory activity in $\mathrm{AD}$-induced rats at the all tested doses. In deep agreement with our findings Satheesh Kumar et al. (2010) reported that fenugreek fractions and saponin namely trigonelline extracts exhibited high AChE inhibitory activity. Additionally, they found that fenugreek saponin, trigonelline, exhibited higher AChE inhibitory activity than other fenugreek fractions. Moreover, Sharififar et al. (2012) indicated that between 3 different plants, fenugreek fraction extract showed high AChE inhibitory activity.

One of the novel strategies of AD therapy is to enhance the cholinergic activity during the pathway of AChE inhibition through using several natural products. Whereas, the major function of $\mathrm{AChE}$ is to transfer the impulse of the nervous cells through the cholinergic connection by the acetylcholine decomposition (Rahman and Choudhary, 2001). Therefore, the main point of the AChE inhibition pathway is cutting the nerve signal through the transmission role of AChE. For that reason, one of the important tools is to find natural products or extracts having the properties to improve the cognitive deficiency. This point was verified in the present study, where fenugreek saponin exhibited the AChE inhibition activity. It has been suggested that the AChE inhibition activity increased with increase the presence of antioxidants in the extracted plant (Sharififar et al., 2012). Depending on this fact, the ability of fenugreek saponin to inhibit $\mathrm{AD}$ due to increase $\mathrm{AChE}$ inhibition activity might be attributed to increase the antioxidants in this herb (Naidu et al., 2011).

The present study reported that fenugreek saponin increased the rates of apoptosis rates in $\mathrm{AD}$-induced rats. The rates of apoptosis were equal to 273.2, 345.1 and $565.9 \%$ in brain tissues of $\mathrm{AD}$-induced rats treated with low, medium and high doses of FS, respectively compared with control rats. In addition, fenugreek saponin increased significantly the mRNA expression levels of apoptotic related genes ( $\mathrm{Bax}, \mathrm{Bcl} 2$ and caspase-3) in $\mathrm{AD}$ induced rats compared with control rats.

In the same line with our findings, Alshatwi et al. (2013) demonstrated that methanol fenugreek extract was able to increase the expression levels of apoptotic and pro-apoptotic genes (such as Caspase 3, Caspase 8, Caspase 9 and Bax) in human breast cancer cell line. They suggested that the activity of fenugreek extract in inducing apoptosis might be attributed to its effect on the two pathways including apoptotic and death receptor pathways.

The main starting place of inducing apoptosis is taking place in the mitochondria. It considered as the central function in caspase cascade regulation and induction of apoptosis (Shafi et al., 2009). It has been found that caspases are the most important molecules in the apoptotic process which they enhance the pathway of the apoptotic cascade (Shah et al., 2003). This pathway is starting with releasing the cytochrome-c from the mitochondrial cells which stimulate the procaspase- 9 and caspase- 3 expression (Shafi et al., 2009). It has been demonstrated that caspase-3 stimulation is found to be the significant step in the apoptotic process (Alshatwi et al., 2013) and play an important role with caspase- 8 and 9 in initiation of the apoptotic pathway (Riedl and Shi, 2004).

Pommier et al. (2004) suggested that caspase- 8 is the main molecule in the death receptor pathway, while caspase- 9 is the critical molecule in the mitochondrial apoptotic pathway, in which the caspase-3 is associating with these molecules in regulation the both pathways. In addition, they also reported that the role of caspase- 8 in activation the link between the both pathways is due to enhancement the cleavage of the pro-apoptotic member of the Bcl-2 family.

Furthermore, the apoptotic member Bax plays an important role with Bak molecule in the apoptotic mitochondrial pathway which activating indirectly the p53 molecule causing cytochrome-c induction followed by apoptosis. This chain of activation steps in the apoptotic pathway enhances the function of caspase- 3 indirectly by Caspase- 8 and 9 or directly by caspase- 9 (Alshatwi et al., 2013). Although of the fact that generation of ROS in the cells triggers the apoptosis pathway by enhancement the DNA strand breaks (Armstrong et al., 2002; Ding et al., 2016; Alan Mitteer et al., 2015) which was found in the AD-induced rats, our study found that treatment of $\mathrm{AD}$-induced rats with fenugreek saponin decreased the intracellular ROS generation and 
DNA damage compared with those in untreated AD-induced rats. Therefore, our results indicated that enhancement the apoptosis by fenugreek saponin could be attributed mainly to the regulation process of casapse-3, Bax and Bcl-2 in the apoptotic pathway and not by generation of ROS in the brain cells of the AD-induced rats.

\section{CONCLUSION}

The results indicated that FS increased the AChEI and apoptosis activities as well as elevated the gene expression levels of Bax; $\mathrm{Bcl} 2$ and caspase-3 genes in AD-induced rats. However, FS decreased the ROS generation and DNA damage in ADinduced rats compared with control rats. The results suggested that the ability of fenugreek saponin to inhibit $\mathrm{AD}$ due to increase AChE inhibition activity might be attributed to increase the antioxidants in this herb. Moreover, enhancement the apoptosis by fenugreek saponin could be attributed mainly to the regulation process of Bax, Bcl-2 and casapse- 3 in the apoptotic pathway and not by generation of ROS in the brain cells of the AD-induced rats.

\section{Financial support and sponsorship: Nil.}

Conflict of interest: There are no conflicts of interest.

\section{REFERENCES}

Ak T, Gulcin I. Antioxidant and radical scavenging properties of curcumin. Chem Biol Interact, 2008; 174:27-37.

Akhondzadeh S, Noroozian M, Mohammadi M, Ohadinia S, Jamshidi AH, Khani M. Melissa officinalis extract in the treatment of patients with mild to moderate Alzheimer's disease: A double blind, randomised, placebo controlled trial. J Neurol Neurosurg Psychiatry, 2003; 74:863-6.

Alan Mitteer R, Wang Y, Shah J, Gordon S, Fager M, Butter PP, Jun Kim H, Guardiola-Salmeron C, Carabe-Fernandez A, Fan Y. Proton beam radiation induces DNA damage and cell apoptosis in glioma stem cells through reactive oxygen species. Sci Rep, 2015; 5:13961.

Almeshal IA, Parmar NS, Jariq M, Ageel AM. Gastricantiulceractivityin rats of Trigonellafoenumgraecum. Fitoterapia,1985; $56: 232-235$.

Alshatwi AA, Shafi G, Hasan TN, Syed NA, Khoja KK. Fenugreek Induced Apoptosis in Breast Cancer MCF-7 Cells Mediated Independently by Fas Receptor Change. Asian Pacific Journal of Cancer Prevention, 2013; 14:5783- 5788

Armstrong JS, Steinauer KK, Hornung B, Irish JM, Lecane P, Birrell GW, et al. Role of glutathione depletion and reactive oxygen species generation in apoptotic signaling in a human B lymphoma cell line. Cell Death Diffe, 2002; 9:252-63.

Bilal BH, Rizwarul H, Suhel P, Suwarna P, Iqbal S, Raisuddin S. Immunomodulatory effects of fenugreek extract in mice. Int. Immunopharma- Col, 2003; 3, 257-265.

Burda S, Oleszek W. Antioxidant and antiradical activities of flavonoids. J Agric Food Chem, 2001; 49:2774-9.

Candy JW, Perry RH, Perry EK, Irving D, Blessed G, Fairbairn AF. Pathological changes in the nucleus of Meynert in Alzheimer's and Parkinson's diseases. J Neurol Sci, 1983; 59:277-89.

Carageorgious H, Sideris AC, Messaril E. The effect of revastigmine and selegilin on brain acetylcholinesterase, $(\mathrm{Na}+\mathrm{K}+)$, $\mathrm{Mg} 2+$, Atpase activities, antioxidant status and learning performance of aged rats. Neuropsychiatric Disease and Treatment, 2008; 4: 687-699.

Cardenas M, Marder M, Blank VC, Roguin LP. Antitumor activity of some natural flavonoids and synthetic derivatives on various human and murine cancer cell lines. Bioorg Med Chem, 2006; 14:296671.
Collins A, Dusinska M, Franklin M, Somorovska M, Petrovska H, Duthie S, Fillion L, Panayiotidis M, Raslova K. Vaughan N. Comet assay in human biomonitoring studies: Reliability, validation, and applications. Environ. Mol. Mutagen, 1997; 30: 139-146.

Corbiere C, Liagre B, Bianchi A, et al. Different contribution of apoptosis to the antiproliferative effects of diosgenin and other plant steroids, hecogenin and tigogenin, on human 1547 osteosarcoma cells. Int J Oncol, 2003; 22:899-905.

Drever BD, Anderson WG, Riedel G, Kim DH, Ryu JH, Choi DY, et al. The seed extract of cassia obtusifolia offers neuroprotection to mouse hippocampal cultures. J Pharmacol Sci, 2008; 107:380-92.

Ellman GL, Lourtney DK, Andres V, Gmelin G. A new and rapid colorimetric determination of acetylcholinesterase activity. Biochem. Pharma- Col, 1961; 7, 88-95.

Erazi H, Sansar W, Ahboucha S, Gamrani H. Aluminum affects glial system and behavior of rats. C. R. Biol, 2010; 333: 23-27.

Fairbairn DW, Olive PL, O'Neill KL. Comet assay: A comprehensive review. Mutat. Res, 1995; 339, 37-59.

Ding Y, Wang H, Niu J, Luo M, Gou Y, Miao L, Zou Z, Cheng Y. Induction of ROS Overload by Alantolactone Prompts Oxidative DNA Damage and Apoptosis in Colorectal Cancer Cells. Int J Mol Sci, 2016; 17(4).

Gulcin I. Antioxidant activity of caffeic acid (3,4dihydroxycinnamic acid). Toxicology, 2006; 217:213-20.

Heo HJ, Kim MJ, Lee JM, Choi SJ, Cho HY, Hong BS, et al. Naringenin from Citrus junos has an inhibitory effect on acetylcholinesterase and a mitigating effect on amnesia. Dement. Geriatr. Cogn Disord, 2004; 17:151-157.

Hussein MA. Antidiabetic and antioxidant activity of Jasonia montana extract in Streptozotocininduced diabetic rats. Saudi Pharmaceutical J, 2008; 16: 214-221.

Jayaweera DMA. 1981. In: Medicinal Plant: Part III. Peradeniya. Royal Botanic Garden, Sri Lanka; p. 255.

Kaviarasan S, Naik GH, Gangabhagirathi R, Anuradha CV, Priyadarsini KI. In vitro studies on antiradical and antioxidant activities of fenugreek (Trigonella foenum graecum) seeds. Food Chem, 2007; 103,31-37.

Khalil WKB, Booles HF. Protective Role of Selenium Against Over-Expression of Cancer-Related Apoptotic Genes Induced by o-Cresol in Rats. Arh Hig Rada Toksikol, 2011; 62:121-129.

Kim JK, Bae H, Kim MJ, Choi SJ, Cho HY, Hwang HJ, et al. Inhibitory effect of poncirus trifoliate on acetyl cholinesterase and attenuating activity against trimethyltin induced learning and memory impairment. Biosci Biotechnol Biochem, 2009; 73:1105-1112.

Kris-Etherton PM, Hecker KD, Bonanome A, Coval SM, Binkoski AE, Hilpert KF, et al. Bioactive compounds in foods: Their role in the prevention of cardiovascular disease and cancer. Am J Med, 2002; 113:71S-88S.

Li N, Liu JH, Zhang J, Yu BY. Comparative evaluation of cytotoxicity and antioxidative activity of 20 flavonoids. J Agric Food Chem, 2008; 56:3876-83.

Loizzo MR, Tundis R, Menichini F, Menichini F. Natural products and their derivatives as cholinesterase inhibitors in the treatment of neurodegenerative disorders: An update. Curr Med Chem, 2008; 12:1209-28.

Marston A, Oleszek W. (Eds.). 2000. Saponins in food, feedstuffs and medicinal plants. Springer, Netherlands.

Moalic S, Liagre B, Corbiere C, et al. A plant steroid, diosgenin, induces apoptosis, cell cycle arrest and COX activity in osteosarcoma cells. FEBS Lett, 2001; 506:225-30.

Mukherjee PK, Kumar V, Mal M, Houghton PJ. In vitro acetylcholines-terase inhibitory activity of essential oil and its main constituents of Acorus calamus. Planta Med, 2007; 73,283-285.

Naidu MM, Shyamala BN, Naik JP, Sulochanamma G, Srinivas P. Chemical composition and antioxidant activity of the husk and endosperm of Fenugreek seeds. Food Sci Tech Int, 2011; 44, 451-6.

Natrajan B, Muralidharan A, Satish R, Dhananjayan R. Neuropharmaco- logicial activity of Trigonella foenum graecum Linn. Seeds. J. Nat. Rem, 2007; 160-165. 
Pommier Y, Sordet O, Antony S, Haywrd RL, Kohn KW. Apoptosis defects and chemotherapy resistance: molecular interaction maps and networks. Oncogene, 2004; 23: 2934-49.

Prasad KN, Hovland AR, Cole WC, Prasad KC, Nahreini P, Edwards-Prasad J, et al. Multiple antioxidants in the prevention and treatment of Alzheimer disease: Analysis of biologic rationale. Clin Neuropharmacol, 2000; 23:2-13.

Rahman AU, Choudhary MI. Bioactive natural products as a potential source of new pharmacophores. A theory of memory. Pure and Applied Chemistry, 2001; 73:555-560.

Riedl SJ, Shi Y. Molecular mechanisms of caspase regulation during apoptosis. Nat Rev Mol Cell Biol, 2004; 5:897-907.

SatheeshKumar N., Mukherjee PK, Bhadra S, Saha BP. Acetylcholinesterase enzyme inhibitory potential of standardized extract of Trigonella foenum graecum L and its constituents. Phytomedicine, 2010; 17:292-295

Shafi G, Munshi A, Hasan TN, et al. Induction of apoptosis in HeLa cells by chloroform fraction of seed extracts of Nigella sativa. Cancer Cell Int, 2009; 27:9-29.

Shah S, Gapor A, Sylvester PW. Role of caspase-8 activation in mediating vitamin E-induced apoptosis in murine mammary cancer cells. Nutr Cancer, 2003; 45:236-46.

Sharififar F, Moshafi MH, Shafazand E, Koohpayeh A. Acetyl cholinesterase inhibitory, antioxidant and cytotoxic activity of three dietary medicinal plants. Food Chemistry, 2012; 130:20-23.

Sharma RD, Sarkar A, Hazra DK, Misra B, Singh JB, Maheswari BB. Toxicological evaluation of fenugreek seeds: a long term feeding experiment in diabetic patients. Phytother. Res, 1996; 10: 519 520 .
Terry RD, Masliah E. Physical basis of cognitive alterations in Alzheimer's disease: Synapse loss is the major correlate of cognitive impairment. Ann Neurol, 1991; 30:572-80.

Tohda C, Kuboyama T, Komatsu K. Search for natural products related to regeneration of the neuronal network. Neurosignals, 2005; 14: $34-45$.

Villalba M, Martinez-Serrano A, Borner C, Blanco $\mathrm{P}$, Satrustegui J. NMDA-induced increase in $[\mathrm{Ca} 2+](\mathrm{i})$ and $45 \mathrm{Ca} 2+$ uptake in acutely dissociated brain cells derived from adult rats. Brain Research, 1992; 570(1-2): 347-353.

Warrior PK, Nambiar VPK. Indian Medicinal Plants. Orient Longman, 1995; p. 131

\section{How to cite this article:}

Khalil WKB, Roshdy HM, Kassem SM. The potential therapeutic role of Fenugreek saponin against Alzheimer's disease: Evaluation of apoptotic and acetylcholinesterase inhibitory activities. J App Pharm Sci, 2016; 6 (09): 166-173. 